\title{
Atos Acautelatórios da Autoridade Policial: A Necessária Atualização da Lei Maria da Penha
}

Diana Calazans ManN ${ }^{1}$

\section{INTRODUÇÃo}

Em 7 de agosto de 2006 foi promulgada no Brasil a Lei $n^{\circ}$ 11.340, diploma legal cujo escopo consistia em criar mecanismos para coibir a violência doméstica e familiar contra a mulher, regulamentando o parágrafo 8 do art. 226 da Constituição Federal e dando cumprimento aos tratados firmados pelo Brasil, em especial o da Convenção sobre a Eliminação de Todas as Formas de Discriminação contra as Mulheres e da Convenção Interamericana para Prevenir, Punir e Erradicar a Violência contra a Mulher².

A Lei em comento foi batizada de Lei Maria da Penha, em homenagem a uma das milhares de vítimas de violência domés-

1 Mestranda em Ciências Policiais do Instituto Superior de Ciências Policiais e Segurança Pública (Lisboa, Portugal), na especialização Criminologia e Investigação Criminal; pós-graduada em Gestão de Segurança na Sociedade Democrática pela Universidade Luterana do Brasil; e graduada em Ciências Sociais e Jurídicas pela Universidade Federal de Santa Maria/RS; é Delegada de Polícia Federal desde 2003, atualmente é Chefe da Divisão de Direitos Humanos da Policia Federal (DDH/CGDI/ DICOR/DPF).

2 A convenção Interamericana para Prevenir, Punir e Erradicar a Violência contra a mulher, também conhecida como Convenção de Belém do Pará, foi promulgada através do Decreto Presidencial no 1.973, de $1^{\circ}$ de agosto de 1996, após aprovada por meio do Decreto Legislativo no 107, de 31 de agosto de 1995. O texto está disponível para consulta em http://legis.senado.gov.br/legislacao/ListaTextoIntegral. action?id=122009. 
tica do Brasil, que lutou bravamente pela aprovação da lei e pela punição do seu agressor.

Segundo dados publicados pelo governo brasileiro a Lei Maria da Penha é conhecida por $98 \%$ dos brasileiros e já contribuiu para a redução, em 10\%, na taxa de homicídios de mulheres praticados dentro dos lares. ${ }^{3}$

A Lei Maria da Penha criou os Juizados de Violência Doméstica e Familiar e normas sobre a forma de atendimento às mulheres nas Delegacias de Polícia.

A promulgação dessa lei representou certamente uma grande vitória contra o paradigma da impunidade que cercava a violência doméstica no Brasil.

Segundo o Conselho Nacional de Justiça, a aplicação da Lei Maria da Penha fez com que fossem distribuídos 685.905 procedimentos, realizadas 304.696 audiências, efetuadas 26.416 prisões em flagrante e 4.146 prisões preventivas, entre 2006 e 2011.

Entretanto, essa lei representa apenas um passo na construção de uma sociedade mais justa e equânime para as mulheres. De acordo com o Mapa da Violência, em 2015, morreram 4,8 mulheres a cada grupo de 100 mil. Em face disso, o Brasil ocupa o quinto lugar no ranking de países nesse tipo de crime. Dos 4.762 assassinatos de mulheres registrados em 2013 no Brasil, $50,3 \%$ foram cometidos por familiares, sendo que em $33,2 \%$ destes casos, o crime foi praticado pelo parceiro ou ex-compenheiro. Essas quase 5 mil mortes representam 13 homicídios femininos diários em 2013. ${ }^{4}$

3 Os dados referidos estão publicados no site http://www.brasil.gov.br/cidadania-ejustica/2015/10/9-fatos-que-voce-precisa-saber-sobre-a-lei-maria-da-penha.

4 Dados do site http://www.mapadaviolencia.org.br/pdf2015/MapaViolencia_2015_ mulheres.pdf 
De acordo com Nereu Giacomolli existe um grande vácuo entre a proteção outorgada pela Lei e sua eficácia e efetividade, especialmente em face da falta de implementação das medidas de proteção integral e da insuficiência da resposta penal para a prevenção da violência. ${ }^{5}$

Passados 10 anos da promulgação da Lei, e diante de um quadro de violência contra a mulher de difícil reversão, surge uma proposta de alteração prevendo, entre outras alterações, a possibilidade de concessão de algumas medidas protetivas pelo Delegado de Polícia. Referido projeto tramita sob o número 07/2016.

O projeto de lei em comento foi aprovado na Comissão de Constituição e Justiça do Senado. Entretanto, permanece cercado pela polêmica. Muitas vozes se ergueram para defender e também para atacar o projeto de lei mencionado, resultando em acalorados debates promovidos pelos diversos atores do sistema de justiça envolvidos na aplicação da Lei Maria da Penha e também por representações da sociedade civil de defesa dos direitos das mulheres ${ }^{6}$.

A proposta desse artigo consiste em analisar o projeto de lei em questão e confrontá-lo com a cláusula de reserva de jurisdição, visando analisar a possibilidade de o Delegado de Polícia praticar ato que, na sistemática atual da Lei 11340, é privativo do Juiz de Direito.

5 Giacomolli, Nereu José. O Devido Processo Penal, Abordagem Conforme a Constituição Federal e o Pacto de São José da Costa Rica - Cases da Corte Interamericana, do Tribunal Europeu e do STF. 2a Edição Revista e Ampliada. São Paulo: Editora Atlas S.A., 2015.

6 No dia 21 de junho de 2016 foi realizada uma audiência pública no Senado Federal para discutir o texto do Projeto de lei 07/2016. Dessa audiência participaram membros do Judiciário, Ministério Público, Policias Civis e Federal e entidades de defesa de direitos das mulheres. Mias em http://www12.senado.leg.br/institucional/ procuradoria/comum/parlamentares-debatem-alteracoes-na-lei-maria-da-penha-emaudiencia-publica. 


\section{Origem da Lei Maria da Penha}

Antes de adentrar na proposta de alteração da lei, oportuno fazer menção à origem do referido diploma legal. Não seria justo discutir a necessidade de alteração da Lei Maria da Penha sem render justas homenagens à luta hercúlea dessa brasileira para conseguir a punição de quem, desejando-lhe a morte, por duas vezes atentou contra a sua vida, condenando-a a uma cadeira de rodas.

A história começa a se tornar pública em 1983, ano em que biofarmacêutica Maria da Penha Maia Fernandes sofre dupla tentativa de homicídio, ambas por parte de seu então marido. O agressor, Marco Antônio Heredia Viveiros, colombiano naturalizado brasileiro, economista e professor universitário, atirou contra suas costas enquanto ela dormia, causando-lhe paraplegia irreversível. Posteriormente, tentou eletrocutá-la enquanto ela tomava banho ${ }^{7}$.

Em 1998, decorridos quinze anos do cometimento do crime, inobstante terem havido duas condenações pelo Tribunal do Júri do Ceará (1991 e 19960), o agressor permanecia em liberdade. Em face disso, Maria da Penha, apoiada por organizações não governamentais de defesa dos direitos da mulher, enviou o caso à Comissão Interamericana de Direitos Humanos da Organização dos Estados Americanos (OEA). A petição foi autuada como caso Maria da Penha n. $\stackrel{0}{12} .051$.

Em 2001, a Comissão Interamericana de Direitos Humanos responsabilizou o Estado brasileiro por omissão, negligência e tolerância. Considerou que neste caso se davam as condições de violência doméstica e de tolerância pelo Estado definidas na

7 Disponível em http://www.compromissoeatitude.org.br/o-caso-maria-da-penha-naoea/ 
Convenção de Belém do Pará. A denúncia sobre o caso específico de Maria da Penha foi também uma espécie de evidência de um padrão sistemático de omissão e negligência em relação à violência doméstica e familiar contra as mulheres brasileiras.

Neste sentido, assim se manifestou a Comissão: "considera conveniente lembrar aqui o fato inconteste de que a justiça brasileira esteve mais de 15 anos sem proferir sentença definitiva neste caso e de que o processo se encontra, desde 1997, à espera da decisão do segundo recurso de apelação perante o Tribunal de Justiça do Estado do Ceará. A esse respeito, a Comissão considera, ademais, que houve atraso injustificado na tramitação da denúncia, atraso que se agrava pelo fato de que pode acarretar a prescrição do delito e, por conseguinte, a impunidade definitiva do perpetrador e a impossibilidade de ressarcimento da vítima $(\ldots)^{\prime \prime}$.

No ano de 2001, a Comissão Interamericana de Direitos Humanos em seu Informe n. ${ }^{\circ} 54$ de 20019 , responsabilizou o Estado brasileiro por negligência, omissão e tolerância em relação à violência doméstica contra as mulheres, recomendando, entre outras medidas, a finalização do processamento penal do responsável da agressão, proceder uma investigação a fim de determinar a responsabilidade pelas irregularidades e atrasos injustificados no processo, bem como tomar as medidas administrativas, legislativas e judiciárias correspondentes.

O caso Maria da Penha foi o primeiro caso de aplicação da Convenção de Belém do Pará. A utilização deste instrumento internacional de proteção aos direitos humanos das mulheres e o seguimento das peticionárias perante a Comissão, sobre o cumprimento da decisão pelo Estado brasileiro, foi decisiva para que o processo fosse concluído no âmbito nacional e, posteriormente,

8 Disponível em http://www.cidh.org/annualrep/2000port/12051.htm.

9 Idem. 
para que o agressor fosse preso, em outubro de 2002, quase vinte anos após o crime, poucos meses antes da prescrição da pena. ${ }^{10}$

\section{A Natureza Jurídica das Medidas Protetivas}

Algumas palavras sobre a natureza jurídica das medidas protetivas trazidas de forma inovadora sobre a Lei Maria da Penha também são necessárias.

Considerando a análise perfunctória e o caráter de urgência do qual são revestidas, poderíamos afirmar que se tratam de medidas cautelares nominadas.

Entretanto, uma parte da doutrina mais especializada em sistemas de proteção tem trazido mais luzes sobre esse tema, no sentido de negar a natureza cautelar desses provimentos em face do caráter satisfativo do qual se revestem as medidas, pois vão além do escopo de garantir a punição ao agressor, buscando o resguardo da dignidade da vítima enquanto ser humano.

As medidas cautelares visam, em síntese, "acautelar", proteger, tornar possível e efetivo um futuro e eventual processo principal, no qual o mérito da contenda será decidido. No caso das medidas protetivas, não se trata de proteger futuros e eventuais processos penais ou cíveis.

O processo penal - de responsabilização do agressor pelos delitos em tese cometidos, ou cível - acerca de questões patrimoniais ou guarda de filhos em comum, em nada são afetados por essas medidas e podem não vir a serem propostos. Tomemos como exemplo hipotético a prática de uma violência contra a mulher que ainda não tenha tipificação criminal no ordenamento ju-

10 O relato detalhado do caso pode ser encontrado no livro "Sobrevivi, posso contar" escrito pela própria Maria da Penha, publicado em 1994, com o apoio do Conselho Cearense dos Direitos da Mulher (CCDM) e da Secretaria de Cultura do Estado do Ceará. 
rídico, como a perseguição persistente ou stalking ${ }^{11}$ por exemplo. Esse fato por si só não pode interferir ou obstar a obtenção da medida protetiva requerida, uma vez que a sistemática da Lei Maria da Penha tem como eixo principal o amparo e proteção à mulher e não a punição do agressor.

De outra parte, as cautelares possuem como requisitos para o seu deferimento a fumaça de bom direito e o perigo da demora, os quais precisam ser demonstrados pelo requerente como pressupostos ao seu deferimento.

A definição das medidas protetivas como cautelares imporia obstáculos a concessão das mesmas, onerando a vítima e contrariando o espírito da lei. Na lição de Amon Pires "o deferimento das medidas protetivas não depende do interesse da vítima na persecução penal e, uma vez deferidas as medidas, a manutenção de sua vigência, embora transitória, não depende da propositura de eventual ação cível ou penal". ${ }^{12}$

Portanto, as medidas protetivas de urgência previstas na Lei Maria da Penha consistem em procedimentos autônomos, de caráter satisfativos e precários, uma vez que podem ser revogados ou alterados a qualquer tempo, e tem por objeto proteger os

11 Stalking não está adequadamente tipificado na legislação brasileira como um tipo penal autônomo, embora possa configurar a contravenção de perturbação a tranquilidade prevista no descrita no Decreto-lei no 3.688/41, da Lei das Contravenções Penais. Mais sobre o assunto no artigo de Eduardo Luiz Santos Cabette denominado "Stalking ou assédio por intrusão - relação e aplicabilidade das medidas protetivas de urgência em casos de violência doméstica e familiar contra a mulher", disponível http://eduardocabette.jusbrasil.com.br/artigos/121937129/stalking-ou-assedio-porintrusao-relacao-e-aplicabilidade-das-medidas-protetivas-de-urgencia-em-casos-deviolencia-domestica-e-familiar-contra-a-mulher

12 Pires, Amom Albernaz. "A Opção Legislativa pela Política Criminal Extrapenal e a Natureza Jurídica das Medidas Protetivas da Lei." Março de 2015. Disponível em http://www.compromissoeatitude.org.br/a-opcao-legislativa-pela-politica-criminalextrapenal-e-a-natureza-juridica-das-medidas-protetivas-da-lei-maria-da-penha-poramom-albernaz-pires/ 
bens jurídicos tutelados pela Lei Maria da Penha ${ }^{13}$.

\section{Projeto de Lei Câmara No 7 de 2016.}

O projeto de Lei $n^{\text {o }}$ 07/2016 pretende alterar a Lei Maria da Penha para incluir em seu corpo dispositivos que garantam à vítima de violência doméstica atendimento policial e pericial especializado e prestado, preferencialmente, por mulheres.

O projeto prevê ainda a implementação de novos protocolos para a inquirição da mulher agredida, de modo que a inquirição deverá ser realizada com vista a evitar a revitimização, bem como ampliar sua proteção ao estabelecer a proibição de contato direto da vítima com o agressor.

13 Uma outra discussão bastante importante trata do caráter civil ou penal das medidas protetivas. Nereu Giacomolli (2015, pag 57) destaca que uma das críticas à Lei Maria da Penha reside no polimorfismo e hibridismo das medidas protetivas. Mais do que preciosismo doutrinário, a definição tem repercussão prática bastante importante pois, a depender do entendimento, o recurso a ser manejado pelas partes será diferente. A questão ainda não foi pacificada, havendo entendimentos de toda a sorte nos tribunais brasileiros. Em 2014, o STJ proferiu decisão reconhecendo-as como medidas de natureza civil, de caráter autônomo e satisfativo, conforme se depreende do excerto a seguir:

DIREITO PROCESSUAL CIVIL. VIOLÊNCIA DOMÉSTICA CONTRA A MULHER. MEDIDAS PROTETIVAS DA LEI N. 11.340/2006 (LEI MARIA DA PENHA). INCIDÊNCIA NO ÂMBITO CÍVEL. NATUREZA JURÍDICA. DESNECESSIDADE DE INQUÉRITO POLICIAL, PROCESSO PENAL OU CIVIL EM CURSO. 1. As medidas protetivas previstas na Lei n. 11.340/2006, observados os requisitos específicos para a concessão de cada uma, podem ser pleiteadas de forma autônoma para fins de cessação ou de acautelamento de violência doméstica contra a mulher, independentemente da existência, presente ou potencial, de processo-crime ou ação principal contra o suposto agressor. 2. Nessa hipótese, as medidas de urgência pleiteadas terão natureza de cautelar cível satisfativa, não se exigindo instrumentalidade a outro processo cível ou criminal, haja vista que não se busca necessariamente garantir a eficácia prática da tutela principal. "O fim das medidas protetivas é proteger direitos fundamentais, evitando a continuidade da violência e das situações que a favorecem. Não são, necessariamente, preparatórias de qualquer ação judicial. Não visam processos, mas pessoas" (DIAS. Maria Berenice. A Lei Maria da Penha na justiça. 3 ed. São Paulo: Editora Revista dos Tribunais, 2012). 3. Recurso especial não provido.

(STJ - Resp.: 1419421 GO 2013/0355585-8, Relator: Ministro LUIS FELIPE SALOMÃO, Data de Julgamento: 11/02/2014, T4 - QUARTA TURMA, Data de Publicação: DJe 07/04/2014). 
Estabelece como prioritária a criação das Delegacias Especializadas de Atendimento à Mulher (DEAMs), de Núcleos Investigativos de Feminicídio e de equipes especializadas para o atendimento e investigação das violências graves contra a mulher.

Por fim, dispões sobre a inclusão do art. 12-B na Lei $\mathrm{n}^{\mathrm{o}}$ 11.340 para possibilitar ao Delegado de Polícia a aplicação provisória das medidas protetivas de urgências previstas no inciso III do art. 22 e nos incisos I e II do art. 23 desta Lei ${ }^{14}$, e a subsequente comunicação ao juiz, no prazo de vinte e quatro horas, para apreciação da decisão.

Aqui reside a principal controvérsia do referido projeto. Na sistemática em vigor, a aplicação das medidas protetivas, sem exceção, é ato atribuído ao Juiz da Vara Especializada em violência doméstica, na ausência da vara especializada, ao Juiz competente por distribuição ou Juiz responsável pelo plantão judicial.

Os críticos do projeto protestam contra a possibilidade de retirar do guarda-chuva do poder judiciário a competência para

14 Os dispositivos mencionados seguem abaixo:

Art. 22. Constatada a prática de violência doméstica e familiar contra a mulher, nos termos desta Lei, o juiz poderá aplicar, de imediato, ao agressor, em conjunto ou separadamente, as seguintes medidas protetivas de urgência, entre outras:

(omissis)

III - proibição de determinadas condutas, entre as quais:

a) aproximação da ofendida, de seus familiares e das testemunhas, fixando o limite mínimo de distância entre estes e o agressor;

b) contato com a ofendida, seus familiares e testemunhas por qualquer meio de comunicação;

c) frequentação de determinados lugares a fim de preservar a integridade física e psicológica da ofendida;

IV - restrição ou suspensão de visitas aos dependentes menores, ouvida a equipe de atendimento multidisciplinar ou serviço similar;

V - prestação de alimentos provisionais ou provisórios.

Art. 23. Poderá o juiz, quando necessário, sem prejuízo de outras medidas:

I - encaminhar a ofendida e seus dependentes a programa oficial ou comunitário de proteção ou de atendimento;

II - determinar a recondução da ofendida e a de seus dependentes ao respectivo domicílio, após afastamento do agressor; 
o deferimento de medidas protetivas, pois seria ato jurisdicional estrito senso, função incumbida ao judiciário, não podendo ser exercida pelo Delegado de Polícia, servidor público atrelado ao poder executivo e, portanto, inapto a proferir a jurisdição.

Mas, vejamos mais detalhadamente o que significa a cláusula de reserva de jurisdição e qual a o entendimento da doutrina e jurisprudência pátria sobre o tema.

\section{A Atuação do Delegado de Polícia}

O projeto de Lei n⿳ำ 07/2016 pretende conferir ao Delegado de polícia a atribuição de conceder medidas protetivas previstas na Lei Maria da Penha. Vejamos então qual a natureza das funções exercidas pelo Delegado.

De acordo com o art. 144, $\S 4^{\circ}$, da Constituição Federal, ao Delegado de Polícia compete a direção da polícia civil, órgão cuja função consiste no exercício da segurança pública, através da preservação da ordem pública e da incolumidade das pessoas e do patrimônio, conforme inserido no caput do referido artigo.

O Código de Processo Penal, por sua vez, dispõe em seu art. $4^{\circ}$ que "a polícia judiciária será exercida pelas autoridades policiais no território de suas respectivas circunscrições e terá, por fim, a apuração das infrações penais e da sua autoria. Nos artigos seguintes, a lei processual enumera diversas atividades que tem por escopo atingir aos fins da polícia judiciária.

É pacifico na doutrina o entendimento de que a autoridade policial a que se refere o Código de Processo Penal é somente o Delegado de Polícia. Segundo lições de Franco Perazzoni o conceito de autoridade está intimamente ligado ao conceito de poder estatal. Assim, somente podem ser considerados autorida- 
des aqueles servidores públicos que exercem, em nome próprio, o poder do estado, estando investidos de poderes de decisão e mando, especialmente da possibilidade de restringir bens jurídicos e direitos individuais. ${ }^{15}$

As tarefas incumbidas aos Delegados de Polícia pelo Código de Processo Penal em seus primeiros artigos tratam do início da investigação, quando a notícia criminal é levada ao conhecimento da autoridade policial, seja pelo cidadão ao registrar uma ocorrência, seja através de comunicação por outro órgão público.

Ao longo da lei processual outros artigos tratam da atuação do Delegado de Polícia, visando o desenvolvimento e conclusão do inquérito policial e o encerrando na fase de investigação.

Importante frisar que as tarefas atribuídas ao Delegado pelo Código de Processo Penal são meramente exemplificativas e atualmente complementadas por leis esparsas que foram sendo promulgadas para dar resposta a criminalidade moderna, sobretudo ao crime organizado nacional e transnacional, fenômeno surgido depois do advento do CPP.

Em 2013, a Lei no 12.830 sepultou de vez o questionamento sobre a natureza jurídica do cargo de Delegado de Polícia, bem como sobre sua função de autoridade policial. A referida lei estabelece que compete ao Delegado de Polícia, na qualidade de autoridade policial, a condução da investigação criminal por meio de inquérito policial ou outro procedimento previsto em lei, que tenha como objetivo a apuração das circunstâncias, da materialidade e da autoria das infrações penais.

A Lei no 12.830/2013 estabelece o poder requisitório do

15 Perazzoni, Franco. (2011). O Delegado De Polícia No Sistema Jurídico Brasileiro: Das Origens Inquisitoriais ao Garantismo Penal de Ferrajoli. Revista Brasileira de Segurança Pública e Cidadania, Volume 4, p. 77 a 110. Acessado em 05 de novembro de 2016, disponível em https://periodicos.pf.gov.br/index.php/RSPC/article/view/113/149. 
Delegado, ao lhe conferir a prerrogativa de requisitar perícias, informações, documentos e dados que interessem à apuração dos fatos. Além de tratar do ato de indiciamento, estabelecendo-o como privativo do Delegado de Polícia, mediante a realização de análise técnico-jurídica do fato, com indicação de autoria, materialidade e circunstâncias do fato.

O diploma legal reconhece o Delegado de Polícia como autoridade policial que exerce uma função jurídica e técnica, restringindo as causas de redistribuição de investigações pelos superiores hierárquicos e a possibilidade de remoções imotivadas para outros locais. Esses dispositivos têm por escopo impedir a redistribuição das investigações através da via oblíqua da remoção ou mesmo a remoção como forma de punição.

Esse importante marco legal foi elaborado com o intuito de conferir garantias necessárias a uma atuação imparcial e técnica desse servidor público a quem incumbe a condução do inquérito policial, fazendo as vezes de Estado-investigação.

Ainda de acordo com Franco Perazoni ${ }^{16}$ :

Nesta esteira, o delegado de polícia, como titular do Estado-investigação, no Estado Democrático de Direito possui, portanto, tripla função: a) proteger os bens jurídicos mais importantes e ameaçados pela conduta humana; $b$ ) apurar as supostas práticas delituosas que the cheguem a conhecimento com zelo, imparcialidade e em estrita consonância com os ditames de um sistema processual de partes, portanto democrático e marcadamente acusatório19 e; c) proteger o próprio suspeito/investigado/indiciado dos excessos e arbítrios outrora cometidos pelo próprio estado, tendo em vista a sua condição de indivíduo, titular de garantias e direitos fundamentais.

Dentre essa gama de atribuições, das quais se destacam a investigação, compete ao Delegado de Polícia decidir sobre a

16 Idem. 
prisão em flagrante e ou representar pela prisão preventiva do investigado.

Sobre o poder decisório do delegado de polícia, Ruchester Marreiros Barbosa destaca o caráter cautelar de certas medidas que estão na alçada de decisão do Delegado, lecionando que a decisão sobre a prisão em flagrante tem natureza cautelar processual, pois encerra uma decisão sobre a possibilidade de o cidadão, em situação flagrancial, recolher a fiança e responder em liberdade. Dessa forma, compete ao Delegado de Polícia decidir sobre direitos fundamentais do investigado, nesse caso, o direito fundamental liberdade, restringido por determinação de prisão em flagrante ou liberdade provisória mediante fiança.

Segue o ilustre doutrinador, in verbis:

Em outras palavras, a reserva absoluta da jurisdição não significa que o Estado-investigação não possa praticar atos de natureza decisória[11], pelo contrário, a Constituição e as normas infraconstitucionais preveem medidas acautelatórias e requisições pela Autoridade de Garantias, v.g. arts. 23, VII, 30 e 31 da Lei 12.527/11, artigo 17-B da Lei 9.613/98, artigo $2^{\circ}$, §2º da lei 12.830/2013 e artigo 15 da lei 12.850/2013, mas que a toda evidência não estão no âmbito de incidência da reserva absoluta da jurisdição. Neste caso, os atos são praticados sem prejuízo do controle judiciário, conforme dispõe o artigo 5ㅁ, XXXV da CRFB, mas com fundamento igualmente constitucional, conforme artigo $5^{o}$, XXXIII da $\mathrm{CR} / 88^{17}$.

Por fim, cumpre destacar que o cargo de delegado de polícia é provido por concurso público de provas e títulos, dele podendo participar somente bacharéis em direito, dado o caráter jurídico das funções que exerce.

17 Barbosa, Ruchester Marreiros. “Delegado possui função imanente de decisão e de cautelaridade da prova." Consultor Jurídico. 08 de Dezembro de 2015. Disponível em http://www.conjur.com.br/2015-dez-08/academia-policia-delegado-possui-funcaoimanente-decisao-cautelaridade-prova. Acesso em 05 de novembro de 2016. 


\section{A Cláusula de Reserva de Jurisdição}

Segundo Gomes Canotilho ${ }^{18}$, a cláusula de reserva de jurisdição nada mais é do que uma decorrência lógica do princípio de separação dos poderes, uma vez que cumpre a cada um dos poderes exercer as funções que lhes foram atribuídas, em face de serem considerados os órgãos mais adequados para a tarefa. Assim, de forma bastante simples e didática: compete ao legislativo elaborar as leis, ao executivo o seu cumprimento e execução e ao judiciário a função de julgar, dizendo a última palavra sobre os atos praticados pelos demais poderes e sobre os litígios em geral. Cada um dos poderes exerce a função para a qual está mais apto.

Certamente, essa divisão não tem caráter absoluto. Visando o equilíbrio entre os poderes, são admitidas exceções, como é o caso das medidas provisórias, através das quais o executivo pode legislar; das Comissões Parlamentares de Inquéritos, ou CPIs, a quem a Constituição Federal atribuiu a função de investigar e julgar; entre outras exceções.

Entretanto, esse intercâmbio de competências tem um limite, que consiste em respeitar o núcleo essencial de cada um dos poderes e suas funções. No que tange ao poder judiciário, a cláusula de reserva de jurisdição é o mecanismo utilizado para garantir o respeito a esse núcleo duro da função jurisdicional. ${ }^{19}$

A doutrina brasileira ainda não se debruçou profundamente sobre o princípio da reserva de jurisdição, motivo pelo qual vamos nos socorrer da acurada definição de Gomes Canotilho que analisa a reserva de jurisdição pelo critério das duas

18 Apud Vilares, Fernanda Regina. "A Reserva de Jurisdição No Processo Penal: Dos Reflexos no Inquérito Parlamentar." Teses da Universidade de São Paulo. 2010. Disponível em http://www.teses.usp.br/teses/disponiveis/2/2137/tde-23112010-082016/publico/ DISSERTACAO_Fernanda_Vilares_239_fls.pdf. Acesso em 08 de novembro de 2016.

19 Idem. 
palavras, diferenciando o "monopólio da última palavra" do "monopólio da primeira palavra". ${ }^{20}$

O monopólico da última palavra poderia ser traduzido pela preservação do acesso à justiça, pois mesmo no caso de haver apreciação em âmbito administrativo o prejudicado sempre poderia submeter sua contenda à apreciação judicial.

A segunda acepção, ou "monopólio da primeira palavra", ocorre quando "a competência do juiz para implica a exclusão de qualquer outro pronunciamento anterior, havendo um monopólio, por assim dizer, absoluto"21.

O monopólio da primeira palavra tem incidência nos casos em que há uma expressa e específica previsão constitucional, como, por exemplo, na decretação de uma prisão. Nesses casos a reserva de jurisdição está explícita no texto constitucional, é reserva absoluta de jurisdição. Assim, não poderá haver apreciação de outras instâncias ou atos administrativos sobre decretação de prisão, concessão de mandado de busca ou interceptação das comunicações.

No que tange ao posicionamento jurisprudencial pátrio, o Supremo Tribunal Federal examinou a questão de forma incidental em ações impetradas contra atos de Comissões Parlamentares de Inquérito, as quais, por força do art. 58, §3으, da Constituição Federal possuem poderes de investigação próprios das autoridades judiciais, conforme segue:

POSTULADO CONSTITUCIONAL DA RESERVA DE JURISDIÇÃO: UM TEMA AINDA PENDENTE DE DEFINIÇÃO PELO SUPREMO TRIBUNAL FEDERAL. O postulado da reserva constitucional de jurisdição importa em submeter, à esfera única de decisão dos magistrados, a práti-

20 Idem.

21 Idem. 
ca de determinados atos cuja realização, por efeito de explícita determinação constante do próprio texto da Carta Política, somente pode emanar do juiz, e não de terceiros, inclusive daqueles a quem se haja eventualmente atribuído o exercício de "poderes de investigação próprios das autoridades judiciais". A cláusula constitucional da reserva de jurisdição que incide sobre determinadas matérias, como a busca domiciliar (CF, art. 5․ XI), a interceptação telefônica (CF, art. 5ㅁ, XII) e a decretação da prisão de qualquer pessoa, ressalvada a hipótese de flagrância (CF, art. 5ํ, LXI) - traduz a noção de que, nesses temas específicos, assiste ao Poder Judiciário, não apenas o direito de proferir a última palavra, mas, sobretudo, a prerrogativa de dizer, desde logo, a primeira palavra, excluindo-se, desse modo, por força e autoridade do que dispõe a própria Constituição, a possibilidade do exercício de iguais atribuições, por parte de quaisquer outros órgãos ou autoridades do Estado. Doutrina. - O princípio constitucional da reserva de jurisdição, embora reconhecido por cinco (5) Juízes do Supremo Tribunal Federal - Min. CELSO DE MELLO (Relator), Min. MARCO AURÉLIO, Min. SEPÚLVEDA PERTENCE, Min. NÉRI DA SILVEIRA e Min. CARLOS VELLOSO (Presidente) - não foi objeto de consideração por parte dos demais eminentes Ministros do Supremo Tribunal Federal, que entenderam suficiente, para efeito de concessão do writ mandamental, a falta de motivação do ato impugnado. (MS 23452, Relator (a): Min. CELSO DE MELLO, Tribunal Pleno, julgado em 16/09/1999, DJ 12-05-2000 PP00020 EMENT VOL-01990-01 PP-00086) ${ }^{22}$

O princípio constitucional da reserva de jurisdição - que incide sobre as hipóteses de busca domiciliar (CF, art. 5ํㅡ, XI), de interceptação telefônica (CF, art. 5․, XII) e de decretação da prisão, ressalvada a situação de flagrância penal (CF, art. $5^{\circ}$, LXI) - não se estende ao tema da quebra de sigilo, pois, em tal matéria, e por efeito de expressa autorização dada pela própria $C R\left(C F\right.$, art. 58, $\S 3^{\stackrel{o}{o}}$ ), assiste competência à CPI, para decretar, sempre em ato necessariamente motivado, a

22 Retirado do site do Supremo Tribunal Federal, disponível em http://www.stf.jus.br/ portal/jurisprudencia/visualizarEmenta.asp?s1=000020700\&base=baseAcordaos 
excepcional ruptura dessa esfera de privacidade das pessoas. Autonomia da investigação parlamentar. O inquérito parlamentar, realizado por qualquer CPI, qualifica-se como procedimento jurídico-constitucional revestido de autonomia e dotado de finalidade própria, circunstância esta que permite à Comissão legislativa - sempre respeitados os limites inerentes à competência material do Poder Legislativo e observados os fatos determinados que ditaram a sua constituição - promover a pertinente investigação, ainda que os atos investigatórios possam incidir, eventualmente, sobre aspectos referentes a acontecimentos sujeitos a inquéritos policiais ou a processos judiciais que guardem conexão com o evento principal objeto da apuração congressual.

[MS 23.652, rel. min. Celso de Mello, j. 22-11-2000, P, DJ de 16-2-2001.] = HC 100.341, rel. min. Joaquim Barbosa, $j$. 4-11-2010, P, DJE de 2-12-2010.23

Assim, de acordo com as decisões da Suprema Corte, a cláusula de reserva de jurisdição foi reconhecida para os casos em que a própria Constituição Federal, expressamente, exige que a restrição a determinado direito fundamental somente se proceda mediante decisão judicial.

Quando não houver a menção expressa à necessidade de ordem judicial, como no caso do afastamento do sigilo fiscal, outras autoridades podem determinar o seu levantamento.

Importante consignar que o legislador infraconstitucional pode considerar necessária a apreciação judicial acerca de determinada matéria, estabelecendo esse requisito em lei ordinária ou complementar. É o caso por exemplo da Lei no ${ }^{-12.965 / 2014, ~ t a m-~}$ bém conhecida como Marco Civil da Internet. A Lei em questão dispôs que o provedor responsável pela guarda de registros de conexão e de acesso a aplicações de internet somente será obrigado a disponibilizá-los mediante ordem judicial. Ora, os regis-

23 Disponível em http://www.stf.jus.br/portal/constituicao/artigobd.asp?item=\%20760 
tros de conexão, conforme já sedimentado em diversas decisões judiciais, não se confundem com o conteúdo da comunicação, este sim, somente passível de afastamento por ordem judicial, conforme explicitado na Constituição Federal. Embora possam revelar dados da vida íntima e privada do cidadão, não houve menção sobre a necessidade de ordem judicial para a liberação desses dados.

Embora não fosse necessário submeter a requisição de registros de conexão à exame judicial, essa foi a opção do legislador. Nada obsta, entretanto, que outra lei no futuro possa considerar desnecessária a ordem judicial, deixando a questão na alçada de decisão de outras autoridades públicas, diversas do judiciário, como os Delegados de Polícia e Ministério Público, uniformizando o tratamento dos registros de conexão com o tratamento conferido aos demais dados cadastrais, que podem ser requisitados a critério das referidas autoridades.

Nos casos em que a necessidade de provimento judicial está prevista em lei, não há que se falar em reserva absoluta de jurisdição, pois alterando-se a norma infraconstitucional, uma instância administrativa poderá tratar da questão, ou seja, dizer a primeira palavra sobre a situação. Resguardada a possibilidade de o judiciário dizer a palavra final.

A questão que permanece em discussão refere-se à existência de uma reserva de jurisdição implícita, ou seja, mesmo inexistindo previsão expressa na constituição de necessidade de decisão judicial, haveria temas que somente o Judiciário poderia decidir. Especialmente nos casos que tratam de conflitos envolvendo direitos fundamentais.

Parte da doutrina considera suficiente para que haja incidência da cláusula de reserva de jurisdição que a decisão tenha por objeto a restrição de um direito fundamental. Esse entendi- 
mento, entretanto, traz enormes dificuldades para sua aplicação, uma vez que amplia sobremaneira o guarda-chuva do poder judiciário e retira a cogência das normas de direito público.

A existência de uma cláusula de reserva de jurisdição implícita poderia inviabilizar o funcionamento normal do estado. Imaginemos as ordens diárias expedidas pelos órgãos públicos e cumpridas diuturnamente, como a retirada de veículos de determinados locais (restrição da propriedade), o fechamento de ruas e desvios de trânsito (restrição do direito de locomoção), determinação para desocupação de casas em caso de risco (restrição ao direito a propriedade e moradia), fechamento de estabelecimentos comerciais pela vigilância sanitária (restrição a atividade econômica), entre outros. Todas essas atividades somente poderiam ser praticadas pelo poder executivo após obtenção de ordem judicial pois restringem direitos fundamentais constitucionalmente reconhecidos.

Somos do entendimento de que a necessidade de ordem judicial ou, em outras palavras, a incidência da reserva de jurisdição, ocorre quando a restrição ao direito é de tal ordem que atinge o núcleo do direito fundamental protegido constitucionalmente. Restrições outras, desde que não sejam desse jaez, podem ser determinadas por outros órgãos do estado, permanecendo a reserva de jurisdição no que tange a apreciação de eventual futuro litígio (monopólio da última palavra).

Assim, no que tange as medidas protetivas previstas no artigo 22, inciso III e artigo 23, incisos II, da Lei no 11.340 , especialmente com relação ao imediato afastamento do agressor do lar determinado pelo Delegado de Polícia, não há violação à cláusula de reserva de jurisdição, pois os direitos fundamentais do agressor não são afetados em seu núcleo, uma vez que podem ser exercidos em alguma medida. Não se trata de perda da liberdade, da propriedade ou possível atentado contra a inviola- 
bilidade do domicílio. Trata-se da imposição de uma restrição de acesso até que um juiz aprecie a questão, o que deverá ser feito no prazo de vinte e quatro horas.

Importante também analisar a situação pela perspectiva da vítima, e não apenas em face dos direitos do agressor. Atualmente, é a vítima quem deixa a casa até que uma ordem judicial seja deferida. De modo que, além de ter sido agredida ou ameaçada e estar sob risco de vida, precisará sair de sua residência para a manutenção da própria integridade física, psicológica e quiçá da própria vida.

\section{Conclusão}

Nessas breves linhas, foram tecidos comentários sobre a origem da Lei Maria da Penha, como resposta brasileira às determinações da Comissão Interamericana de Direitos Humanos, e sobre persistência da violência contra a mulher na sociedade brasileira passados 10 anos da promulgação do novo marco legal.

Também foram redigidas algumas linhas sobre a natureza jurídica das medidas protetivas, as quais não podem ser classificadas como cautelares cíveis ou penais, em face de seu caráter híbrido e polimorfo, para usar as palavras de Nereu Giacomolli24; satisfativo quanto ao mérito e precário quanto à duração.

Foram feitas considerações acerca das funções exercidas pelo Delegado de Polícia, as quais são de natureza técnico-jurídica, privativas de bacharéis em direito, que encerram o poder decisório do Estado-investigação e como tal devem ser dotadas de técnica e imparcialidade.

24 Giacomolli, Nereu José. O Devido Processo Penal, Abordagem Conforme a Constituição Federal e o Pacto de São José da Costa Rica - Cases da Corte Interamericana, do Tribunal Europeu e do STF. 2a Edição Revista e Ampliada. São Paulo: Editora Atlas S.A., 2015: p. 51. 
Mencionamos que o Delegado de Polícia tem, constitucionalmente, competência para decidir sobre a prisão em flagrante e competência legal quanto ao arbitramento de fiança, atos de natureza eminentemente cautelar, uma vez que visam assegurar a efetividade do futuro processo penal, e que afetam integralmente direitos fundamentais constitucionalmente assegurados. Referidos atos não são admitidos como jurisdicionais, mas também não são inquinados como violadores da reserva de jurisdição.

Não é objetivo desse ensaio defender que o Delegado de Polícia tenha competência para dizer a jurisdição. Entretanto, não se pode negar que a determinação da prisão em flagrante é medida que afeta o núcleo do direito fundamental à liberdade e tem sido manejada pelo Delegado de Polícia sem maiores questionamentos, uma vez que prevista constitucionalmente.

Essa aceitação pela carta constitucional se dá em face da necessidade de pacificação social que está ínsita na medida em questão, ou seja, na prisão de alguém que está cometendo ou acabou de cometer um crime. Assim, se o Delegado de Polícia pode decidir sobre a restrição total da liberdade, ao determinar a prisão em flagrante e o subsequente recolhimento ao cárcere, também poderá determinar o afastamento do agressor do lar, medida com caráter bem menos gravoso, mas extremamente importante para a preservação da vida da mulher vítima de violência doméstica.

Foi dito que a cláusula de reserva de jurisdição é reconhecida pelo Supremo quando expressamente mencionada no texto constitucional. Nesses casos é expressa e absoluta.

Também foi mencionado que o Supremo não admitiu até o presente momento a existência de uma cláusula de reserva de jurisdição implícita. Reconheceu como válidas as normas que conferem poderes ao Fisco e as Comissões Parlamentares de In- 
quérito para levantar sigilo fiscal e bancário, por não haver disposição constitucional expressa em contrário.

O mesmo pode ser afirmado com relação a requisição de dados cadastrais, os quais podem ser requisitados pelas autoridades não-judiciais pois não estão sob o manto do direito constitucional ao sigilo das comunicações, embora afetem o direito fundamental à privacidade. Exemplo disso são os dispositivos da Lei 12.830 que conferem poderes de requisição aos Delegados de Polícia.

Diante desse quadro, a transferência ao Delegado de Polícia da prerrogativa de determinar o afastamento do lar e de outras medidas protetivas previstas na Lei n⿳ำ 11.340/2006 não fere a cláusula de reserva de jurisdição, uma vez que não existe uma norma constitucional que exija o provimento judicial para o ato.

Ademais, o ato administrativo será submetido ao controle judicial no prazo de 24 horas, sendo passível de confirmação ou correção pelo juiz que o apreciará.

Vale ainda ressaltar que as críticas acerca da precariedade do ato praticado pelo Delegado de Polícia não esvaziam, desmerecem ou invalidam o ato, pois é da própria natureza jurídica das medidas protetivas o caráter precário, vez que podem ser alteradas, levantadas ou revogadas a qualquer tempo.

Assim, o afastamento do agressor da residência coabitada por agressor e agredida é medida protetiva que pode ser manejada pela autoridade policial uma vez que não tem conteúdo jurisdicional e estará submetida a posterior e obrigatório controle judicial, ficando desde sempre assegurado o monopólio judicial da última palavra.

Importante repisar que o Delegado de Polícia, no exercício de sua atividade, analisará a situação fática e somente deter- 
minará a medida naqueles casos em que ficar convencido que houve violência doméstica e que a vítima está em risco de ser novamente agredida se permanecer coabitando com o agressor.

Veja-se que a alteração proposta pelo PL 07/2016 inverte o atual estado de coisas, pois atualmente a vítima é quem precisa sair de casa e se socorrer de casas de acolhimento, nem sempre disponíveis, até que sobrevenha a ordem judicial, situação que não se coaduna com o espírito de proteção da Lei Maria da Penha e nem com os ditames da Convenção de Belém do Pará.

Por fim, o art. $7^{\circ}$ da Convenção de Belém do Pará dispõe como dever dos estados partes a adoção de medidas jurídicas que exijam do agressor que se abstenha de perseguir, intimidar e ameaçar a mulher ou de fazer uso de qualquer método que danifique ou ponha em perigo sua vida ou integridade ou danifique sua propriedade.

A norma em questão está inserida em tratado internacional de Direitos Humanos ratificado pelo Brasil. De acordo com o Art. 5 o , §3으, da Constituição Federal "os tratados e convenções internacionais sobre direitos humanos que forem aprovados, em cada Casa do Congresso Nacional, em dois turnos, por três quintos dos votos dos respectivos membros, serão equivalentes às emendas constitucionais". A ratificação da Convenção de Belém ocorreu antes Emenda Constitucional 45, quando não havia distinção de rito para a ratificação dos tratados de direitos humanos. Sendo assim, abalizadas vozes, como entendem que referidos tratados estão em igualdade de posição hierárquica com as normas constitucionais ${ }^{25}$.

Portanto, o Projeto de Lei n. 07/2016, além de não ferir cláusula de reserva de jurisdição, confere aplicabilidade ao arti-

25 Motta, Sylvio. "A hierarquia legal dos tratados internacionais". Consultor Jurídico, Setembro de 2009. Disponível em http://www.conjur.com.br/2009-set-18/convencaodireitos-pessoas-deficiencia-status-ec. Acesso em 15 de novembro de 2016. 
go sétimo da Convenção de Belém do Pará ao criar mecanismo jurídico que permitem a cessação, sem mais delongas, da agressão ou ameaça a que está submetida a vítima.

\section{REFERÊNCIAS BibLIOGRÁfiCAS}

ALMEIDA, Pierre. “Comissões Parlamentares de Inquérito, poderes, limitações e respeito aos direitos e garantias fundamentais." Jus Navigandi. 2015. https://jus.com.br/ artigos/35963/comissoes-parlamentares-de-inquerito (acesso em 06 de novembro de 2016).

BARBOSA, Ruchester Marreiros. "Delegado possui função imanente de decisão e de cautelaridade da prova." Consultor Jurídico. 08 de Dezembro de 2015. http://www. conjur.com.br/2015-dez-08/academia-policia-delegadopossui-funcao-imanente-decisao-cautelaridade-prova (acesso em 05 de novembro de 2016).

BARBOSA, Ruchester Marreiros. “O poder requisitório como função judicial atípica do Delegado." Canal Ciências Criminais. 20 de abril de 2016. https://canalcienciascriminais. com.br/o-poder-requisitorio-como-funcao-judicial-atipicado-delegado/ (acesso em 30 de outubro de 2016).

BARROSO, Luis Roberto. Curso de Direito Constitucional Contemporâneo. 2a Edição. São Paulo: Saraiva, 2010.

CABETTE, Eduardo Luiz Santos. “Stalking ou assédio por intrusão - relação e aplicabilidade das medidas protetivas de urgência em casos de violência doméstica e familiar contra a mulher." JusBrasil. s.d. http://eduardocabette. jusbrasil.com.br/artigos/121937129/stalking-ou-assedio-porintrusao-relacao-e-aplicabilidade-das-medidas-protetivasde-urgencia-em-casos-de-violencia-domestica-e-familiarcontra-a-mulher (acesso em 15 de Novembro de 2016). 
COMISSÃO Interamerica de Direitos Humanos. Relatório $N^{\circ}$ 54/01: Caso 12.051 Maria da Penha Maia Fernandes - Brasil. 4 de Abril de 2001. http://www.cidh.org/ annualrep/2000port/12051.htm (acesso em 15 de Novembro de 2016).

FULCO, Ana Carolina de Carvalho. "Violência doméstica: Brasil e EUA." Jus Navigandi. 11 de setembro de 2012. https://jus.com.br/artigos/22593/combate-a-violenciadomestica-no-brasil-contribuicao-a-partir-da-experiencianorte-americana (acesso em 28 de outubro de 2016).

GIACOMOLLI, Nereu José. O Devido Processo Penal, Abordagem Conforme a Constituição Federal e o Pacto de São José da Costa Rica - Cases da Corte Interamericana, do Tribunal Europeu e do STF. 2a Edição Revista e Ampliada. São Paulo: Editora Atlas S.A., 2015.

JÚNIOR, Edison Botelho Silva. "Tratados de direitos humanos e sua equivalência constitucional." Âmbito Jurídico. s.d. http://www.ambito-juridico.com.br/site/index.php?n_ link=revista_artigos_leitura\&artigo_id=2340 (acesso em 15 de Novembro de 2016).

LOPES, Carina Deolinda da Silva. "Procedimentos e atribuições do delegado de polícia e das polícias judiciárias." Âmbito Jurídico. s.d. http://www.ambito-juridico.com.br/site/ index.php?n_link=revista_artigos_leitura\&artigo_id=3052 (acesso em 05 de novembro de 2016).

MAGALHÃES, Huacy Ragner Amaral de. “Comissão parlamentar de inquérito e a cláusula constitucional da reserva de jurisdição." Conteúdo Jurídico. 28 de Outubro de 2016. http://www.conteudojuridico.com.br/ artigo,comissao-parlamentar-de-inquerito-e-a-clausulaconstitucional-da-reserva-de-jurisdicao,36404.html.

MATEUS, Elizabeth do Nascimento. "A Lei Maria da Penha e os direitos humanos da mulher no contexto internacional." 
Âmbito Jurídico. 2010. http://www.ambito-juridico.com. br/site/index.php/..\%5C..\%5CWINDOWS\%5CApplicati on\%20Data\%5CQualcomm\%5CEudora\%5CL7210.htm?n_ link=revista_artigos_leitura\&artigo_id=8243\&revista_ caderno=16 (acesso em 15 de Novembro de 2016).

MOTTA, Sylvio. "A hierarquia legal dos tratados internacionais." Conjur. 18 de Setembro de 2009. http:// www.conjur.com.br/2009-set-18/convencao-direitospessoas-deficiencia-status-ec (acesso em 15 de Novembro de 2016).

"O Caso Maria da Penha na Comissão de Direitos Humanos da OEA." Compromisso e Atitude. 19 de agosto de 2912. http:// www.compromissoeatitude.org.br/o-caso-maria-dapenha-na-oea/ (acesso em 28 de outubro de 2016).

PERAZZONI, Franco. “O Delegado de Polícia no Sistema Jurídico Brasileiro: Das Origens Inquisitoriais ao Garantismos Penal de Ferrajolli." Revista Brasileira de Segurança Pública \& Cidadania, Brasília, v. 4, n. 2, p. 77-110, jul/dez 2011. https://periodicos. pf.gov.br/index.php/RSPC/article/view/113/149 (acesso em 05 de novembro de 2016).

PINTO, Guilherme Newton do Monte. A Reserva de jurisdição. s.d. http://www.dominiopublico.gov.br/download/teste/ arqs/cp125225.pdf (acesso em 2016).

PIRES, Amom Albernaz. "A Opção Legislativa pela Política Criminal Extrapenal e a Natureza Jurídica das Medidas Protetivas da Lei." Compromisso e Atitude. Março de 2015. http://www.compromissoeatitude.org.br/wpcontent/uploads/2014/09/AMOMALBERNAZPIRES_ naturezajuridicadasmedidasprotetivasMPDFT2011.pdf (acesso em 30 de outubro de 2016).

ROMEU, Olavo Augusto Vianna Alves Ferreira e Luciana Campanelli. CF deu ao fisco autoridade para identificar 
patrimônio. Conjur. 23 de Julho de 2010. http://www. conjur.com.br/2010-jul-23/cf-deu-fisco-autoridadeidentificar-patrimonio-rendimentos\#author (acesso em 06 de Novembro de 2016).

SANTOS, Alexandre Cesar dos. "Delegado de Polícia: cargo de carreira jurídica." Jusbrasil. 2016. http://acsufpe.jusbrasil. com.br/artigos/327539776/delegado-de-policia-cargo-decarreira-juridica (acesso em 05 de Novembro de 2016).

VILARES, Fernanda Regina. A Reserva de Jurisdição No Processo Penal: Dos Reflexos no Inquérito Parlamentar. USP. 2010. http://www.teses.usp.br/ teses/disponiveis/2/2137/tde-23112010-082016/publico/ DISSERTACAO_Fernanda_Vilares_239_fls.pdf (acesso em 08 de novembro de 2016). 